\title{
THE IMPORTANCE OF SOCIAL TRANSFERS IN REDUCING POVERTY IN CROATIA
}

Predrag Bejakovića

a Senior researcher, Ph.D, The Institute of Public finance, , Smičiklasova 21, Zagreb, Croatia, predrag@ijf.hr

\section{ARTICLE INFO}

Keywords:

- social transfer,

- poverty,

- Croatia

\begin{abstract}
The current social protection system in Croatia is a mix of old and new programs that are continuously being reformed in response to changing social needs and opportunities to provide social transfers or services more efficiently. In the paper after introduction remarks, theoretical framework on social transfers is provided. Economic growth and poverty indicators are explained in Section 2, while Section 3 is dedicated to the trend of total social costs in Croatia. International comparisons and analysis of social transfer efficiency in Croatia are given in Section 4. Section 5 is devoted to conclusion and recommendations with priority of better adjustment of social transfers towards most vulnerable groups.
\end{abstract}

Reference to this paper should be made as follows: Bejaković. P. 2013. The importance of social transfers in reducing poverty in Croatia, Ekonomska istraživanja - Economic Research Special Issue 2013 
Predrag Bejaković

\section{INTRODUCTION}

Although Croatia has relatively high social expenditures (about $26 \%$ of GDP), many are of the opinion that they are not sufficiently effective in the reduction of inequality and poverty (for example Jafarov and Gunnarsson, 2008). The analyses have shown that expenditures inside the large programmes (pensions) are less strongly oriented towards the poor, while those programmes on which fewer financial resources are spent (welfare benefits) are directed more strongly to the impoverished. But a better insight into the effectiveness of transfers will be given by a comparative analysis, through which we can compare the effectiveness of the Croatian transfer system with the transfer systems of developed and transitional countries.

The current social protection system in Croatia is a mix of old and new programs that are continuously being reformed in response to changing social needs and opportunities to provide social transfers or services more efficiently. Some of these programs were inherited from the socialist period, such as pensions and family benefits. Other programs have been added since, such as maintenance allowance, which were initiated during the 1990s to meet the needs of a market economy, and needs-based social assistance programmes.

A significant number of Croatian citizens suffer from bad social conditions and lack adequate access to public goods and services, while due to the recession, increased unemployment and budgetary problems, we can expect further deterioration of the social image (although it is difficult to accurately predict and plan the number of unemployed and poverty-stricken persons). In order to alleviate the crisis, the Government is proposing and implementing appropriate measures regarding economic and fiscal policy. The Government is trying to formulate the measures pursuant to the principle of social justice, i.e. equal allocation of the burden of crisis and fiscal consolidation among all categories of society. In that sense, the Government promised not to reduce the existing social rights. The key factor is to prevent a substantial increase in unemployment and to ensure adequate conditions for quicker employment in case of dismissal.

The text is dedicated to the description of activities on economic recovery in Croatia, with particular attention to the role of social transfers. The paper consists of five sections. After these introduction remarks, Section 1 provides theoretical framework on social transfers, primarily their definition, types and importance. Economic growth and poverty indicators are explained in Section 2, while Section 3 is dedicated to the trend of total social costs in Croatia. International comparisons and analysis of social transfer efficiency in Croatia are given in Section 4. Section 5 is devoted to conclusion and recommendations with priority of better adjustment of social transfers towards most vulnerable groups.

\section{THEORETICAL FRAMEWORK}

Scientific and political discussions in the world often quarrel about the efficiency of welfare programmes realised primarily through social transfers because it is stated that the welfare system - like many other expressions of human intention - contains a seed of corruption. Often, it is stated - but only partly justified - that excessive and long-term unemployment benefits or significant rights in the welfare system (which is not the case in Croatia) encourage the unemployed and poor to a longer and more selective job search, as well as to lower work efforts and earlier withdrawal from employment. Formally huge expenditures for welfare purposes are not a guarantee of efficient targeting and use. The situation with welfare program efficiency is particularly unfavourable in transitional countries where the (limited available) resources are mostly not very well targeted towards the most vulnerable groups in society. Also, some programmes that are at 
first glance costly or luxurious maybe really help poor people, while some others - less expensive or generous - actually do not have any effect (or the effect is very weak) on reducing and palliating poverty. Thus it, is necessary constantly to monitor and survey the implementation of particular programs.

The term social transfers encompasses a wide range of instruments - from short term reactive humanitarian assistance in times of emergency, to long term, pre-planned and predictable support to those entrapped in poverty, or in danger of becoming entrapped. However, the current interest in social transfers in post-transitional countries is focused on the potential of long term predictable instruments to address chronic poverty and its causes. To safeguard their predictability, social transfers require reliable and therefore on-budget resources. This aspect of social transfers has raised many concerns amongst cash-strapped governments in southern and eastern European countries.

Social transfers are organized through various social security schemes. These schemes can be classified in two major groups, according to their financing mechanisms: contributory schemes and non-contributory schemes. In Croatia like in any given country, several schemes of different types generally co-exist and may provide benefits for similar contingencies to different population groups. In contributory schemes the contributions made by beneficiaries (and their employers) determine entitlement to benefits. The most common form of contributory scheme is of a statutory social insurance scheme (for example pension insurance) which usually covers employees and registered self-employed. Mentioned contributory schemes are mostly financed through contributions, but in Croatia due to relatively huge pension expenditures (around $12 \%$ of GDP) are also financed with budget transfers and public revenues collected by taxes or other sources. There are also non-contributory interventions in contributory schemes subsidizing either benefits or contributions for specified groups of members and beneficiaries. Conversely, non-contributory schemes normally require no direct contribution from beneficiaries or their employers as a condition of entitlement to receive benefits. Non-contributory schemes are usually financed through tax or other state revenues and may be either targeted to the poor or not.

Non-contributory schemes not targeted towards the poor (non-means-tested schemes) consist of universal schemes for all residents provide benefits under the single condition of residence like guarantee access to health care; and categorical schemes focus on specific groups of the population like those that transfer income to the elderly above a certain age or children below a certain age. Non-contributory schemes targeted towards the poor (non-means-tested schemes) comprise targeting mechanisms that ensures that these programmes cover only those people whose means (usually their assets or income) fall under a certain threshold. Such targeted schemes are very diverse in their design and features. This diversity may manifest itself through the methods of targeting that are employed, the supplementary conditions required for beneficiaries to access benefits and the inclusion of other interventions that are delivered on top of the actual income transfer itself. Such non-contributory schemes include various benefits and programmes like non-conditional minimum income support schemes (or social assistance schemes) that provide cash benefits and/or benefits in kind to poor people usually based on some form of means-test; conditional cash transfers that provide cash benefits to poor people subject to the condition that they fulfil specific "behavioural" requirements, for example obligation of the parents to ensure their children attend school regularly; employment guarantee schemes that ensure access to a certain number of workdays per year to poor households, generally providing wages at a relatively low level usually through public works programmes. 
Predrag Bejaković

Most social transfers are designed to support household consumption, but they also facilitate productive investment, health improvement, education participation etc. The effect is larger where regular, predictable and adequate transfers enable income, assets and credit constrained households to reallocate their productive resources, and accumulate and protect their assets (International Labour Office, 2010).

\section{ECONOMIC GROWTH AND POVERTY INDICATORS: THE CASE OF CROATIA}

As the (un)employment status in Croatia significantly determines the economic situation of individual person and members of his or her family, there is a need to provide some basic facts of GDP trends and briefly explain a situation on the labour market. After respective GDP growth rates of about 4\% over a number of years from 2001 to 2007, in 2008 Croatia's GDP started to display growth retardation: from $4.3 \%$ in the first quarter to $1.6 \%$ in the third quarter, so for the whole year GDP growth was only 2.2\%. After significant GDP decrease -6.0\% in 2009 and $-124 \%$ 2010, 2011 was characterised by stagnation and zero GDP growth. Mentioned economic trends have had direct negative impact on the labour market, primarily in decrease in the number of employed persons and related increase in the number of employed persons (Table 1).

TABLE 1 BASIC ECONOMIC INDICATORS FOR 2007- 2011 (GROWTH RATES IN \%)

\begin{tabular}{|c|c|c|c|c|c|}
\hline & 2007 & 2008 & 2009 & 2010 & 2011 \\
\hline GDP & 5.1 & 2.2 & -6.0 & -1.2 & 0 \\
\hline Real net wages & 2.2 & 0.8 & 0.2 & -0.5 & -0.4 \\
\hline Total employment according to administrative sources & 3.3 & 2.5 & -3.6 & -4.4 & -2.5 \\
\hline Total unemployment ${ }^{1)}$ & -9.3 & -10.5 & 11.2 & 15.4 & 1,0 \\
\hline Registered unemployment rate & 14.8 & 13.2 & 14.9 & 17.4 & 17.9 \\
\hline LFS unemployment rate ${ }^{2)}$ & 9.6 & 8.4 & 9.1 & 11.8 & 12.2 \\
\hline
\end{tabular}

Source: Croatian Employment Service, Croatian Bureau of Statistics

Labour Force Survey data, from 2007 to 2010, the average of three-month rates. Data for 2011 refer to the third quarter.

The overall unemployment rate for the population aged 15- 64 fell from 13 per cent in 2005 to 9 per cent in 2008. In 2009 and 2010 the unemployment rate increased to 10 and to 12 per cent respectively. Compared to men, whose average unemployment rate remained below 10 per cent, women experience rates of unemployment in the range of 12 per cent. However, since the economic sectors that suffered most during the crisis are male-dominated, the percentage increase in the unemployment rate for men in the period from 2008 to 2010 equalled 4 percentage points (from 7 to 11 per cent), while for women it increased by 2 percentage points (from 10 to 12 per cent). Mentioned trends even deteriorated till 2012.

The at-risk-of-poverty rate began to rise at the beginning of the economic crisis ( $18 \%$ in 2009 in relation to $17.4 \%$ in 2008). In 2010, the at-risk-of-poverty rate was $20.6 \%$, which is considerably higher than the EU27 average (16.4\%). It increased further in 2011 to $21.1 \%$. In 2010 and 2011 , there were no deeper changes in the poverty profile. Still in 2009, relative poverty among the children and youth grew in 2009 (in addition to the oldest age group, children at the age of up to 15 showed the at-risk-of-poverty rate above the national average). In 2010, the at-risk-of-poverty rate for children in the group $0-17$ (20.5\%) is at the national average level, while at-risk-of-poverty 
rates for youths in the group 18-24 (21.6\%) and persons over 64 years of age (28.1\%) are above average. Mentioned data on gender and age of people exposed to at-risk-of-poverty do not exist yet for 2011, but will be available soon. Thus, detail analysis of at-risk-of-poverty rate by age and gender should be oriented towards the data for 2010 (Table 2).

TABLE 2 AT-RISK-OF-POVERTY RATES IN THE REPUBLIC OF CROATIA 2001-2011, $\%$

\begin{tabular}{|c|c|c|c|c|c|c|c|c|c|c|c|}
\hline & 2001 & 2002 & 2003 & 2004 & 2005 & 2006 & 2007 & 2008 & 2009 & $2010^{1)}$ & $2011^{1)}$ \\
\hline At-risk-of-poverty rate & 17.2 & 18.2 & 16.9 & 16.7 & 17.5 & 16.3 & 17.4 & 17.4 & 18.0 & 20.6 & 21.1 \\
\hline \multicolumn{12}{|c|}{ At-risk-of-poverty rate by age and gender } \\
\hline$-M$ & 15.4 & 17.7 & 15.8 & 15.1 & 15.9 & 15.1 & 15.9 & 15.5 & 16.1 & 19.8 & \\
\hline$-F$ & 18.7 & 18.6 & 17.9 & 18.1 & 18.9 & 17.4 & 18.7 & 19.1 & 19.9 & 21.4 & \\
\hline $0-15$ years $\left.^{2}\right)$ & 15.9 & 16.7 & 15.2 & 14.8 & 19.7 & 13.8 & 15.4 & 15.4 & 19.2 & $\ldots$ & \\
\hline$-M$ & 13.9 & 17.9 & 15.6 & 13.7 & 18.2 & 14.1 & 14.9 & 15.0 & 19.0 & $\ldots$ & \\
\hline$-F$ & 18.0 & 15.4 & 14.7 & 15.9 & 21.3 & 13.5 & 16.0 & 15.8 & 19.3 & $\ldots$ & \\
\hline $16-24$ years ${ }^{2}$ & 15.2 & 16.4 & 15.4 & 13.1 & 15.3 & 11.9 & 15.0 & 14.4 & 16.0 & $\ldots$ & \\
\hline$-M$ & 16.9 & 19.0 & 16.2 & 13.5 & 15.9 & 12.6 & 14.2 & 13.7 & 16.0 & $\ldots$ & \\
\hline$-F$ & 13.6 & 13.5 & 14.6 & 12.7 & 14.7 & 11.1 & 15.9 & 15.2 & 16.1 & $\ldots$ & \\
\hline 65 years or more & 28.5 & 29.0 & 27.9 & 29.5 & 25.6 & 29.5 & 29.0 & 31.2 & 31.5 & 28.1 & \\
\hline$-M$ & 23.5 & 25.6 & 23.6 & 24.4 & 20.9 & 26.9 & 25.2 & 26.2 & 23.7 & 23.3 & \\
\hline$-F$ & 31.8 & 31.2 & 30.6 & 32.9 & 28.5 & 31.3 & 31.4 & 34.4 & 36.5 & 31.3 & \\
\hline \multicolumn{12}{|c|}{ At-risk-of-poverty rate by most frequent activity status and gender } \\
\hline Employed & 5.2 & 5.8 & 5.2 & 4.4 & 3.9 & 2.8 & 4.1 & 3.7 & 4.4 & 5.0 & 5.3 \\
\hline$-M$ & 6.0 & 6.6 & 6.0 & 4.5 & 5.0 & (3.3) & 5.0 & 4.8 & 5.7 & 6.4 & \\
\hline$-F$ & 4.1 & 4.9 & (4.3) & $(4.3)$ & $(2.7)$ & $(2.1)$ & (3.1) & $(2.4)$ & $(2.7)$ & 3.5 & \\
\hline Unemployed & 32.2 & 35.0 & 32.4 & 32.0 & 33.4 & 31.2 & 34.5 & 32.6 & 37.4 & 44.7 & 42.5 \\
\hline$-M$ & 35.6 & 42.5 & 39.7 & 39.4 & 36.9 & 34.6 & 42.8 & 39.3 & 40.7 & 51.4 & \\
\hline$-F$ & 29.6 & 28.1 & 26.6 & 25.7 & 30.0 & 28.5 & 27.0 & 27.1 & 34.7 & 37.7 & \\
\hline Pensioners & 21.3 & 23.2 & 20.7 & 20.5 & 19.3 & 22.7 & 22.8 & 23.4 & 24.3 & 23.2 & 22.2 \\
\hline$-M$ & 19.4 & 23.7 & 20.3 & 20.5 & 19.1 & 23.6 & 22.3 & 21.2 & 21.9 & 22.0 & \\
\hline$-F$ & 22.9 & 22.9 & 21.0 & 20.5 & 19.5 & 22.1 & 23.1 & 25.1 & 26.3 & 24.1 & \\
\hline \multicolumn{12}{|c|}{ At-risk-of-poverty rate by household type and age } \\
\hline Single household & 33.3 & 35.1 & 34.7 & 35.9 & 31.1 & 38.1 & 36.5 & 39.8 & 43.2 & 44.8 & \\
\hline$-M$ & 22.4 & 28.6 & 28.3 & 27.6 & $(22.1)$ & 34.0 & 27.9 & 31.1 & 28.2 & 39.8 & \\
\hline$-F$ & 36.7 & 37.5 & 37.3 & 40.5 & 34.2 & 39.8 & 39.8 & 43.3 & 50.2 & 47.0 & \\
\hline $\begin{array}{l}\text { One person household, } \\
\text { person between } 30 \text { and } \\
64\end{array}$ & 26.1 & 26.2 & $(24.7)$ & 28.1 & 25.7 & 29.0 & 28.2 & 28.0 & 30.6 & $\ldots$ & \\
\hline $\begin{array}{l}\text { One person household, } \\
\text { person aged } 65 \text { and more }\end{array}$ & 40.4 & 41.2 & 41.8 & 41.9 & 35.2 & 43.8 & 41.5 & 47.8 & 50.9 & 50.2 & \\
\hline
\end{tabular}


continued table

\begin{tabular}{|c|c|c|c|c|c|c|c|c|c|c|}
\hline $\begin{array}{l}\text { Two adults with no de- } \\
\text { pendent children, both } \\
\text { aged under } 65\end{array}$ & 11.9 & 16.3 & 11.8 & 14.4 & 12.3 & 13.6 & 17.7 & 16.4 & 14.4 & 22.5 \\
\hline $\begin{array}{l}\text { Two adults with no de- } \\
\text { pendent children, at least } \\
\text { one } 65+\end{array}$ & 27.5 & 30.1 & 26.1 & 28.7 & 25.6 & 29.0 & 28.7 & 28.1 & 28.7 & 22.5 \\
\hline $\begin{array}{l}\text { Other households with } \\
\text { no dependent children }\end{array}$ & 9.7 & 9.4 & 9.3 & 9.0 & 7.7 & 10.6 & 8.9 & 6.9 & 7.2 & 11.9 \\
\hline $\begin{array}{l}\text { Single parent with one or } \\
\text { more dependent chil- } \\
\text { dren }\end{array}$ & 28.9 & 27.7 & $(29.1)$ & 21.0 & 34.8 & 32.9 & $(26.0)$ & 40.4 & $(24.5)$ & 34.6 \\
\hline $\begin{array}{l}\text { Two adults with one } \\
\text { child }\end{array}$ & 13.0 & 11.2 & 14.9 & 9.8 & 12.8 & 11.7 & 11.2 & 10.7 & 12.1 & 20.6 \\
\hline $\begin{array}{l}\text { Two adults with two } \\
\text { children }\end{array}$ & 14.9 & 12.8 & 13.7 & 10.5 & 13.1 & 8.2 & 10.1 & 12.8 & 14.1 & 16.5 \\
\hline $\begin{array}{l}\text { Two adults with three } \\
\text { and more children }\end{array}$ & 15.9 & 24.9 & 19.1 & 24.2 & 31.0 & 24.5 & 25.9 & 18.9 & 31.7 & 33.1 \\
\hline $\begin{array}{l}\text { Other households with } \\
\text { dependent children }\end{array}$ & 16.8 & 15.0 & 13.0 & 13.1 & 13.4 & 8.0 & 12.3 & 11.6 & 11.9 & 16.1 \\
\hline \multicolumn{11}{|c|}{ At-risk-of-poverty rate by tenure status } \\
\hline Tenant or subtenant & 20.7 & 18.9 & 20.2 & $(10.5)$ & 21.6 & 19.3 & 21.4 & 20.9 & 26.3 & 20.5 \\
\hline Owner or free housing & 17.0 & 18.1 & 16.8 & 17.0 & 17.3 & 16.2 & 17.2 & 17.2 & 17.8 & 20.6 \\
\hline
\end{tabular}

Source: Croatian Bureau of Statistics Poverty indicators various years.

* Poverty indicators for RC from 2001 to 2009 were calculated from the data on the total net income collected by statistical research Household Budget Survey (HBS) that was carried out on a sample of randomly selected private households, so that the sample for each year was defined separately, i.e. there is no panel sample (households are not repeated in the following year). For 2010 and 2011 poverty indicators were calculated on the basis of the Statistics on Income and Living Conditions survey results. The indicators are based on a concept of relative poverty, which takes into consideration the disposable household income, the number of household members (household size) and the income distribution within the population.

( ) Insufficiently reliable data

1) Poverty indicators to 2009 were calculated from the HBS, while those calculated for 2010 and 2011 were calculated from the data from Statistics on income and living conditions (SILC). Due to the methodological differences between the two data sources, indicators for 2010 and 2011 are not directly comparable with indicators from previous years.

2) According to methodology of calculation, the indicator for listed age groups is not calculated in 2010 and in 2011, while for 2011 gender data are yet not available.

As mentioned, while in the period from 2005 to 2008 there was a stagnant trend in the total at-risk-of-poverty rate (around 17\%), there was simultaneously an evident trend of growth of the mentioned rate among single households (39.8\% in 2008 in comparison with $31.1 \%$ in 2005), and especially among older single households (47.8\% in 2008 in comparison with $35.2 \%$ in 2005). In 2007 the at-risk-of-poverty rate among single households decreased to $36.5 \%$, but increased afterwards to $39.8 \%$ in $2008,43.2 \%$ in 2009 and to $44.8 \%$ in 2010 . Similar trend has been obvious among older single households where after the decrease to $41.5 \%$ in 2006 in comparison with $43.8 \%$ in 2005 , there was a strong increase in 2008 and 2009 , to $47.8 \%$ and $50.9 \%$ respectively. Due to the lack of data it is still impossible to provide a reliable estimation about the continuity of the slight decrease in 2010 when for one person household for person aged 65 and more was recorded at-risk-of-poverty rate of $50.2 \%$.

The at-risk-of-poverty rate of pensioners was by approximately $30 \%$ higher than the national average, but the at-risk-of-poverty rate of elderly people who do not receive pension benefits was by $170 \%$ higher than the national average. It is estimated that in Croatia there are ap- 
proximately $13 \%$ of people above 64 years of age who do not receive any pension benefits (women account for more than $95 \%$ of this cohort) (Ministry of Health and Social Welfare, 2009). Elderly people without pensions who live in single households are at the most unfavourable economic position. In relation to the average, the at-risk-of-poverty rate for the elderly dropped somewhat in 2010 in relation to 2009 .

In the period from 2006 to 2009, the difference between the at-risk-of-poverty rates for men and women grew. In 2010, the difference was 1.6 percentage points, which is considerably less than in 2009, when it was 3.8 percentage points. The greatest difference between the at-risk-ofpoverty rates for men and women is in the eldest age group (65+). The said difference continued to rise from 2006 ( 4.4 percentage points) to 2009 (12.8\% percentage points). In 2010, the at-riskof-poverty rate for elderly women was by 8 percentage points higher than for men.

In comparison with 2008, in 2009 the at-risk-of-poverty rates grew significantly among children, the unemployed, single households with older citizens/women, families with 3 or more children and subtenants (data on at-risk-of-poverty rates for single-parent families in 2009 are unreliable). In 2009, the highest increase in at-risk-of-poverty rates in comparison with 2008 was recorded for households with 3 or more children (by 12.8 percentage points). During the same period, the at-risk-of-poverty rates for children $(0-15)$ grew by 3.8 percentage points, the at-riskof-poverty rates for the unemployed by 4.8 percentage points and the at-risk-of-poverty rates for subtenants by 5.4 percentage points. The at-risk-of-poverty rates for households with two adults and one or two children, as well as of other households with dependent children increased moderately in 2009, but still remained below the national average. The at-risk-of-poverty rates for pensioners increased moderately in 2009 when compared to 2008 (less than 1 percentage point) and is $35 \%$ higher than the national average. In 2010, the at-risk-of-poverty rate for children in the group $0-17(20.5 \%)$ is at the national average level, while at-risk-of-poverty rates for youths in the group $18-24(21.6 \%)$ and persons over 64 years of age (28.1\%) are above average. In relation to the average, the at-risk-of-poverty rate for the elderly dropped somewhat in 2010 in relation to 2009.

It is quite obvious that many people are at the risk-of-poverty in Croatia. In the next section is discussed the trend of total social costs in Croatia.

\section{TOTAL SOCIAL COSTS IN CROATIA}

Total social costs in Croatia in 2008 (18.9\% of GDP) and in 2009 (20.6\% of GDP) were significantly lower than in EU27 (26.3\% of GDP in 2008). However, mentioned expenditures in Croatia are higher than in other transition countries (with the exception of Slovenia and Hungary), and are similar to the ones in Poland and the Czech Republic. In Croatia there is a visible trend of a gradual decline of total social expenditures after 2001 (in 2004, total social protection expenditures accounted for $20.1 \%$ of GDP). Data for the period after 2005 confirm the trend of further mentioned decline of the costs. The reasons for a decline in total social expenditures should be sought primarily in a relatively high economic growth till 2009 and a reduction in pension expenditures. Despite relatively high costs, most of the benefits in the social protection system are low. This is particularly so in the case of pensions, the unemployment benefits and social assistance benefits. The social protection system is predominantly public, but there is an increasing privatisation in some social protection sectors (the pension and health systems and the social services system). After the beginning of the crisis, total social costs in GDP increased in 2009 for 0.7 percentage points in comparison with 2008, what is the consequence of negative economic growth and decline of GDP (Table 4). 
TABLE 3 COSTS OF SOCIAL PROTECTION (\% OF GDP)

\begin{tabular}{|c|c|c|c|c|c|c|c|c|c|c|c|c|}
\hline & $R C$ & $R C$ & $R C$ & $R C$ & $R C$ & $R C$ & $R C$ & $R C$ & $R C$ & $R C$ & $R C$ & EU27 \\
\hline & 2001 & 2002 & 2003 & 2004 & 2005 & 2006 & 2007 & 2008 & 2009 & 2010 & $2011^{*}$ & 2008 \\
\hline Total costs & 22.8 & 21.7 & 20.5 & 20.1 & 19.2 & 18.5 & 18.8 & 18.9 & 20.6 & 20.8 & 20.3 & 26.3 \\
\hline $\begin{array}{l}\text { Healthcare jobs and } \\
\text { services }\end{array}$ & 6.2 & 5.8 & 5.6 & 5.7 & 5.1 & 5.1 & 5.5 & 5.6 & 6.1 & 6.2 & 6.0 & \\
\hline $\begin{array}{l}\text { Social insurance jobs } \\
\text { and services }\end{array}$ & 14.5 & 13.9 & 12.0 & 11.7 & 11.4 & 11.0 & 10.7 & 10.9 & 11.9 & 12.3 & 12.1 & \\
\hline $\begin{array}{l}\text { Social welfare jobs } \\
\text { and services }\end{array}$ & 1.7 & 1.5 & 2.4 & 2.2 & 2.3 & 2.1 & 2.1 & 2.0 & 2.1 & 1.8 & 1.8 & \\
\hline $\begin{array}{l}\text { Other costs of social } \\
\text { insurance and social } \\
\text { welfare }\end{array}$ & 0.4 & 0.4 & 0.5 & 0.5 & 0.4 & 0.4 & 0.4 & 0.5 & 0.5 & 0.4 & 0.4 & \\
\hline
\end{tabular}

Source: for Croatia Ministry of Finance (classification according to GFS Manual 1986, MMF); for EU: Eurostat.

* Preliminary data.

Note: Data until 2004 include costs of consolidated central state and costs of unconsolidated local and regional self-government. Because of the discrepancies with analytic elaboration of social funds costs by functions for 2005 and 2006, they are not included in the data for those years. Therefore, the data for 2005 and 2006 represent the unconsolidated sum of the State budget and local and regional self-government unit costs, without the costs of social funds. Starting from 2007, all transactions of social funds are a part of the State budget, and the data for 2007-2011 represent the unconsolidated sum of the State budget and local and regional selfgovernment unit costs.

From 2002, data which refer to local and regional self-government include only the largest 53 units of local and regional self-government, which participate with $70-80 \%$ in the total transactions of local and regional self-government.

With the data for 2010, a reclassification was performed of a part of the State budget expenses in line with the revised classification of activities and projects of the budget according to functions which was applied for 2011. The reclassification for earlier years could not be performed. The ratio of GDP for 2000-2011 is represented on the basis of the existing published revised GDP data.

At the end of 2009, for the first time, data on the structure of social costs according to ESSPROS methodology for the period from 2003 to 2007 were released. According to those data, expenditures for the disability function are relatively high (the share of expenditures for this function in GDP is higher than in EU27); the differences are also smaller between Croatia and EU27 in terms of sickness/health function expenditures or old-age and survivors functions costs (in 2005 the costs of the functions indicated as the share of GDP in the Republic of Croatia were by onethird or one-quarter lower than in EU27) (Ministry of Health and Social Welfare, 2010). There are significant differences particularly with regard to the functions of unemployment, housing and social exclusion. Croatia, together with Bulgaria, Romania and the Baltic countries, has the lowest share of costs for protection from unemployment and for housing and social exclusion. Most of the benefits in the social protection system are low, although the amounts of some benefits grew in 2009. The share of the average pension in average wage has almost remained unchanged since 2008 (40\%), whereas the share of the average unemployment benefit in the average wage grew from $22 \%$ in 2008 to $30.5 \%$ in October 2009, and so did the share of the standard permanent social assistance benefit (support allowance) for an able-bodied single person, which grew from $7.7 \%$ in 2008 to almost $10 \%$ in 2009 . The next section provides an international comparison of social transfers in Croatia and its efficiency. 


\section{INTERNATIONAL COMPARISONS AND ANALYSIS OF SOCIAL TRANSFER EFFICIENCY IN CROATIA}

The at-risk-of-poverty rate began to rise at the beginning of the economic crisis ( $18 \%$ in 2009 in relation to $17.4 \%$ in 2008). In 2010 , the at-risk-of-poverty rate was $20.6 \%$, which is considerably higher than the EU27 average (16.4\%). Only Latvia and Romania had a higher at-risk-of-poverty rate than Croatia, while Bulgaria and Spain had approximately the same at-risk-of-poverty rate as Croatia. The relative at-risk-of-poverty gap in 2010 was $28.6 \%$ (Table 4).

TABLE 4 POVERTY AND INEQUALITY INDICATORS

(ACCORDING TO THE LAEKEN METHODOLOGY)

\begin{tabular}{|c|c|c|c|c|c|c|c|c|c|c|c|c|c|}
\hline & $R C$ & $R C$ & $R C$ & $R C$ & $R C$ & $R C$ & $R C$ & $R C$ & $R C$ & $R C$ & $\begin{array}{l}E U- \\
25\end{array}$ & $\begin{array}{l}E U- \\
15\end{array}$ & $\begin{array}{l}E U- \\
10\end{array}$ \\
\hline & 2001 & 2002 & 2003 & 2004 & 2005 & 2006 & 2007 & 2008 & 2009 & 2010 & 2007 & 2007 & 2007 \\
\hline $\begin{array}{l}\text { At-risk-of-poverty } \\
\text { rate }(\%)\end{array}$ & 17.2 & 18.2 & 16.9 & 16.7 & 17.5 & 16.3 & 17.4 & 17.4 & 18.0 & 20.6 & 16 & 16 & 15 \\
\hline $\begin{array}{l}\text { At-risk-of-poverty rate } \\
\text { before social transfers } \\
\text { (pensions included in } \\
\text { income) }(\%)\end{array}$ & 34.7 & 33.7 & 33.3 & 24.0 & 25.8 & 24.1 & 24.3 & 25.5 & 25.8 & 25.3 & 26 & 26 & 25 \\
\hline $\begin{array}{l}\text { At-risk-of-poverty rate } \\
\text { before social transfers } \\
\text { (pensions excluded } \\
\text { from income) }(\%)\end{array}$ & 42.9 & 40.0 & 42.3 & 41.4 & 43.2 & 41.8 & 41.6 & 43.1 & 41.1 & 32.8 & 32 & 32 & 32 \\
\hline $\begin{array}{l}\text { Relative at-risk-of- } \\
\text { poverty gap (\%) }\end{array}$ & 22.7 & 23.2 & 21.1 & 22.4 & 22.9 & 22.5 & 21.9 & 24.9 & 23.8 & 28.6 & 22 & 22 & 23 \\
\hline
\end{tabular}

Source: for Croatia: Croatian Bureau of Statistics, Household Budget Survey (various years); for EU25. EU15 and EU10: Eurostat.

Note: In the EU15 countries income includes income in cash only, while in other countries (including Croatia) total income comprises both income in cash and income in kind. Income in kind is partly included in total income as it is considered to be an important component of total disposable income in these countries. Income in kind includes e.g. privately produced goods intended for personal consumption (food produced by the household itself) or free services as part of a professional activity.

Note: Poverty indicators for the Republic of Croatia were calculated from the data on the total net income collected by statistical research Household Budget Survey (HBS). The survey was carried out on a sample of randomly selected private households. So that the sample for each year was defined separately, i.e. there is no panel sample (households are not repeated in the following year). Net household income, in addition to cash, also includes income in kind. Poverty indicators, until the introduction of the SILC research (Statistics of Income and Living Conditions) into Croatian statistical system, will be calculated from the data collected by HBS. Since the data for the EU countries are calculated from the data of SILC which is methodologically different from HBS, this should be taken into account in comparing the data for RC and EU countries.

( ) Insufficiently reliable data

Deleeck, Van den Bosch and De Lathouwer (1995) stress that in order to determine to what extent social transfers in total or individually affect the poverty reduction rates; it is simplest to compare so-called pre-transfer income with post-transfer income. The at-risk-of-poverty rate before social transfers is calculated by excluding social transfers when defining the income. This indicator is used in combination with a standard at-risk-of-poverty rate in order to evaluate the impact of social transfers on the risk of poverty (Table 5). 
TABLE 5 POVERTY RATES AND POVERTY RATE REDUCTION IN 2011

\begin{tabular}{|c|c|c|c|c|c|}
\hline Country & $\begin{array}{l}\text { At-risk-of- } \\
\text { poverty } \\
\text { rate, } \%\end{array}$ & $\begin{array}{l}\text { At-risk-of- } \\
\text { poverty rate, } \\
\text { before social } \\
\text { transfers, \% }\end{array}$ & $\begin{array}{l}\text { At-risk-of- } \\
\text { poverty rate, } \\
\text { pensions and } \\
\text { social transfers } \\
\text { excluded, \% }\end{array}$ & $\begin{array}{l}\text { Poverty rate reduction } \\
\text { (difference in percentage } \\
\text { points of at-risk-of-poverty } \\
\text { rate, before and after social } \\
\text { transfers) }\end{array}$ & $\begin{array}{l}\text { Poverty rate reduction } \\
\text { (difference in percentage } \\
\text { points of at-risk-of- } \\
\text { poverty rate, before and } \\
\text { after pension and social } \\
\text { transfers) }\end{array}$ \\
\hline 1 & 2 & 3 & 4 & $5=3-1$ & $6=4-1$ \\
\hline EU 27 & 16.5 & 26.4 & 43.8 & 9.9 & 27.3 \\
\hline Austria & 12.6 & 24.9 & 43.6 & 12.3 & 31 \\
\hline Belgium & 15.3 & 27.8 & 42.0 & 12.5 & 26.7 \\
\hline Bulgaria & 22.4 & 27.3 & 40.7 & 4.9 & 18.3 \\
\hline Czech Rep. & 9.8 & 18.0 & 37.8 & 8.2 & 28 \\
\hline Denmark & 13.0 & 28.4 & 40.4 & 15.4 & 27.4 \\
\hline Estonia & 17.5 & 24.9 & 41.1 & 7.4 & 23.6 \\
\hline Finland & 13.7 & 27.4 & 41.3 & 13.7 & 27.6 \\
\hline France & 14.0 & 24.7 & 44.2 & 10.7 & 30.2 \\
\hline Greece & 21.4 & 24.8 & 44.9 & 3.4 & 23.5 \\
\hline Latvia & 19.3 & 27.3 & 45.7 & 8 & 26.4 \\
\hline Lithuania & 20.0 & 31.8 & 49.4 & 11.8 & 29.4 \\
\hline Luxembourg & 13.6 & 27.2 & 43.8 & 13.6 & 30.2 \\
\hline Hungary & 13.8 & 28.9 & 51.8 & 15.1 & 38 \\
\hline Malta & 15.4 & 22.9 & 36.9 & 7.5 & 21.5 \\
\hline Netherlands & 11 & 20.9 & 36.9 & 9.9 & 25.9 \\
\hline Germany & 15.8 & 25.1 & 44.6 & 9.3 & 28.8 \\
\hline Poland & 17.7 & 24.1 & 43.4 & 6.4 & 25.7 \\
\hline Portugal & 18.0 & 25.4 & 42.5 & 7.4 & 24.5 \\
\hline Romania & 22.2 & 29.1 & 49.8 & 6.9 & 27.6 \\
\hline Slovenia & 13.6 & 24.2 & 40.2 & 10.6 & 26.6 \\
\hline Slovakia & 13.0 & 19.5 & 38.3 & 6.5 & 25.3 \\
\hline Spain & 21.8 & 29.8 & 44.8 & 8 & 23 \\
\hline Sweden & 14 & 27.9 & 42.4 & 13.9 & 28.4 \\
\hline Croatia & 21.1 & 30.7 & 46.7 & 9.6 & 25.6 \\
\hline
\end{tabular}

Source: Croatian Bureau of Statistics (2012) Poverty indicators 2011 - Previous data, first release 14.1.2.

Pre-transfer income implies current income from which all or certain social transfers are excluded, while post-transfer income relates to total available income from all sources (wages, social transfers, profits and so on). First, the number of poor people is determined, so that transfers are excluded from income, and then an analysis is made of how much social transfer, when they are included in total income; contribute to the reduction in the number of the poor. In this manner it is possible to ascertain which social transfers are more and which are less effective from the 
viewpoint of the reduction of poverty. For easier comparison, the same data are provided graphically on Picture 1.

\section{FIGURE 1 POVERTY RATES AND POVERTY RATE REDUCTION IN 2011}

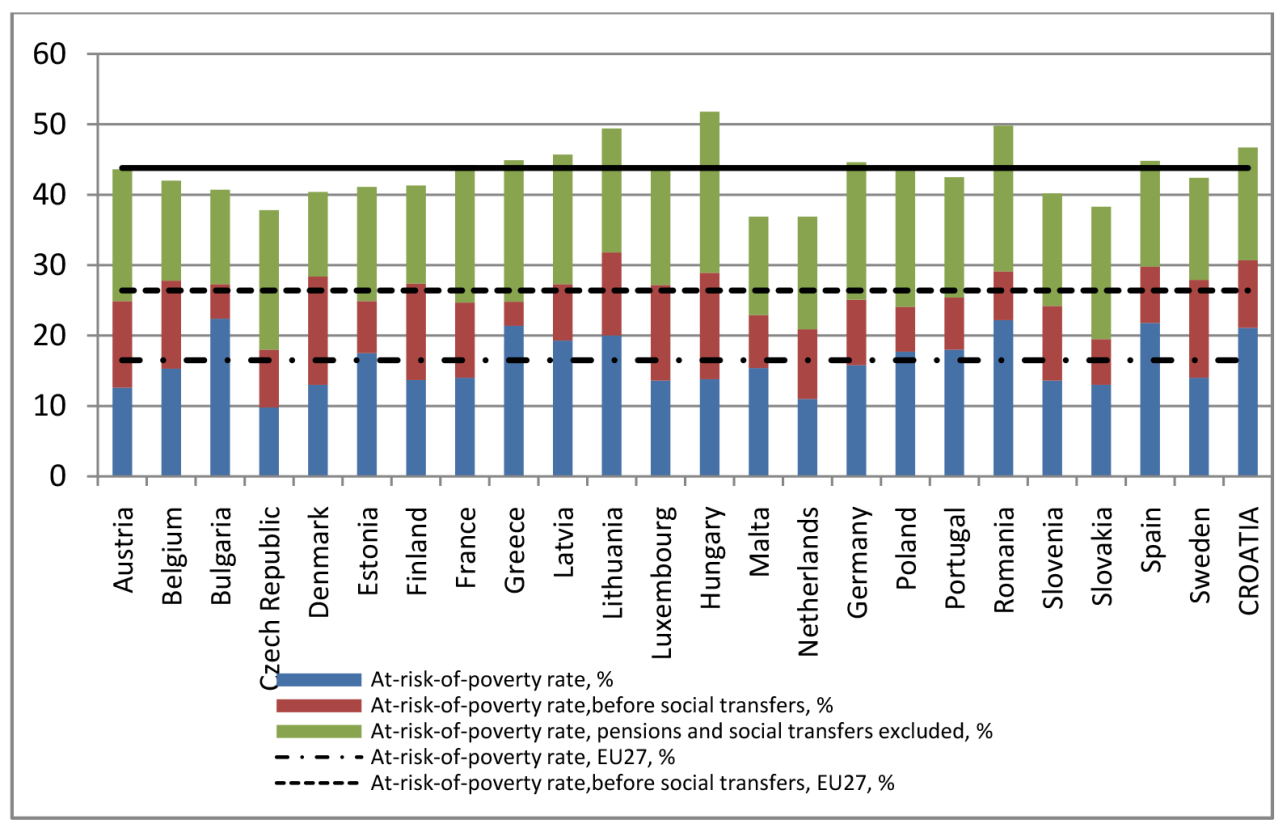

Source: Croatian Bureau of Statistics (2012) Poverty indicators, 2011 - Previous data, first release 14.1.2.

Provided data show differences in poverty rates depending on whether pensions and other social transfers are included or not. The concept of pensions relates only to old-age and survivor pensions and not to disability pensions. On the other hand, the concept of "other social transfers" includes benefits or receipts related to unemployment, child benefits, maternity benefits, layette benefits, sick leave benefits (over 42 days), welfare assistance, benefits for physical impairments and other people's care, benefits for rehabilitation or employment of disabled persons, scholarships and receipts for education and receipts from other persons for housing. This distinction between "other social transfers" on the one hand and old-age and survivor pensions on the other is done according to the Eurostat methodology, for the sake of comparability with EU countries.

As mentioned, for Croatia a comparison between the standard at-risk-of-poverty rate and the at-risk-of-poverty rate before social transfers shows that the exclusion of social transfers caused the increase in the percentage of persons at the risk of poverty from the $21.1 \%$ standard rate to the $30.7 \%$ rate. If both social transfers and pensions were excluded from the income, the at-riskof-poverty rate reached $46.7 \%$. If we analyse the effectiveness of pensions and other social transfers together, it will appear that Croatia has a relatively ineffective transfer system as compared with other countries. Thanks to pensions and other social transfers, the poverty rate reduction in Croatia of 25.6 percentage points is smaller than the EU27 average 27.3 percentage points. In fact, countries can be classified into four groups with respect to the degree to which poverty is reduced: countries in which the rate of poverty reduction is greater than $30 \%$ (the highest in Hungary 38 percentage points, followed by Austria with 31 and France, and Luxembourg with 30.2), countries in which the rate of poverty reduction ranges between 25 and 30\% (Belgium, Czech Republic, 
Predrag Bejaković

Denmark, Finland, Latvia, Lithuania, Netherlands, Germany, Poland, Romania, Slovenia, Slovakia, Sweden, Lithuania), countries with a poverty reduction rate between 20 and 25\% (Estonia, Greece, Malta, Portugal, Spain) and Bulgaria as the only country with a poverty reduction rate lower than 20\%. Mentioned results for Croatia can be surprising because according to Šućur (2005) 2001 Croatia in 2001 had a relatively effective transfer system as compared with other countries. Jafarov and Gunnarsson (2008) believe that unless efficiency of social spending in Croatia will not be improved significantly, further increases in social spending may not lead to less poverty.

\section{CONCLUSION AND RECOMMENDATIONS}

Market forces alone can never be relied on to produce a fair or equitable society. The state must be committed to the reduction of poverty and inequality, and in order to do so, it must maintain a transparent and equitable system of social protection that relies on a foundation of universal coverage and non-discrimination. Social transfers are, in their essential nature, a public responsibility, and are typically provided through public institutions. However, the delivery of social security can be, and often is, mandated to private entities or nongovernmental organizations, which can partially complement selected roles usually played by social security. A wide range of choices and combinations exists regarding the set of financing instruments, the design of benefit entitlements, and administrative arrangements. Each approach has its advantages and its limitations and each will depend on national values, traditions, past experience and institutional frameworks. Most national social security systems combine several types of social transfers. Ultimately, the central objective is that all people enjoy at least a basic level of social security guarantees.

It is necessary to strengthen the social safety net through improved targeting and monitoring of social welfare programmes, empowering civil society in the provision of social services, decentralisation of some social services and better design of employment policy measures. As a crucial measure that would improve the efficiency of social protection spending there is a need to improve the targeting of benefits by significantly expanding the use of means testing in providing benefits. Many positive activities have been performed, but one should recommend that further effort be invested in improving the quality, range and frequency of collecting data, information and social statistics as well as in enhancing research about poverty, economic inequality and social exclusion. Such information and research are required for social planning and for the formulation of appropriate policies. If the objective is for safety nets to reach the poor, information is required on who the poor are and where they are located, and how much of the benefits from the programme are reaching this target group. In most cases, (especially transitional) countries spend significant resources on safety nets but fail to collect data and monitor who receives the benefits and how they were affected by them. Such information should also be made available to the research community and general public. These two steps will help to make government at all levels more accountable to the electorate, by providing voters with more information about the impact of government policies, which should also raise the quality of public debate and increase the participation of citizens in the political decision-making process. This could maybe contribute to better determination of the governmental goals in poverty reduction, improved targeting in implementation of measures and active participation of bodies and individuals on different levels of government.

The measures of social policy and reducing the impact of the crisis on the most endangered citizens are necessary in order to prevent the living standards of the poorest citizens from dropping even lower. The state budget, as well as the local budgets, should not reduce the means of ensuring material rights for the socially endangered groups (social welfare beneficiaries, the 
unemployed, the elderly without pensions, elderly with low pensions, etc.) It is possible that the number of social welfare beneficiaries in the future will not dramatically increase, because most of those that are unemployed will compensate their income loss through unemployment benefits. However, if the unfavourable economic trends continue throughout next period, it is possible to expect an increase in the number of users of different types of social benefits, meaning that in that case additional means and programmes for the most vulnerable groups will have to be activated. The role of the local authorities is crucial, while the local government units should become actively involved in ensuring assistance for the poorest citizens. 


\section{REFERENCES}

Bejaković Predrag and Viktor Gotovac, "Aktivnosti na gospodarskom oporavku u Republici Hrvatskoj s naglaskom na tržište rada" (Activities on Economic Recovery in Croatia, with Particular Attention to the Labour Market), Revija za socialnu politiku, 3 (2011): 331-355.

Deleeck, H., Van den Bosch, K. and De Lathouwer, L., Poverty and the adequacy of social security in the EC, Aldershot: Avebury, 1995.

International Labour Office Effects of non-contributory social transfers in developing countries: A compendium, Geneva: International Labour Office, on line available on www.lo.org/ publns, 2010.

Jafarov Etibar and Victoria Gunnarsson, "Efficiency of Government Social Spending in Croatia", Financial Theory and Practice 3 (2008): 289-320

Ministry of Economy, Labour and Entrepreneurship, Report on the Implementation of the Joint Assessment of the Employment Policy Priorities of the Republic of Croatia for 2009, Zagreb: Ministry of Economy, Labour and Entrepreneurship, 2010.

Ministry of Health and Social Welfare, Report on the Implementation of the Joint Inclusion Memorandum of the Republic of Croatia for the Period from January 2008 to March 2009, Zagreb: Ministry of Health and Social Welfare, 2009.

Ministry of Health and Social Welfare, Report on the Implementation of the Joint Inclusion Memorandum of the Republic of Croatia in 2009, Zagreb: Ministry of Health and Social Welfare, 2010.

Ministry of Social Policy and Youth, Report on the Implementation of the Joint Inclusion Memorandum of the Republic of Croatia in 2011, Zagreb: Ministry of Social Policy and Youth, 2012.

Rawlings Laura and Gloria Rubio, Evaluating the impact of conditional cash transfer programs, World Bank Research Observer, 20, (2005) 29-55. http://www.crin.org/docs/Evaluating\%20 the\%20Imapact\%20of\%20Cash\%20Transfer\%20Programs.pdf

Šućur, Zoran, Poverty and Social Transfers in Croatia, Financial Theory and Practice, 129 (2005): $17-38$

UNDP Croatia, () Quality of Life and Risks of Social Exclusion in the Republic of Croatia, Quantitative research on general population, Zagreb: UNDP, 2006. 